\title{
Roman Catholicism and Eastern Orthodoxy: Can linguistic and semiotic analysis clarify their contrasts?
}

\author{
William J. Sullivan \\ Maria Curie-Skłodowska University (emer.), Poland \\ Sarah Tsiang \\ Eastern Kentucky University, USA
}

\begin{abstract}
The western and eastern branches of Christianity, broadly speaking Roman Catholicism (RC) and Eastern Orthodoxy (EO), have been formally separate for almost a millennium. Yet they share the fundamental dogmas laid down by the first ecumenical councils. History and politics are entwined in the disputes since the Great Schism of 1054, but even earlier there was controversy over basic dogmatic questions and other doctrinal matters. Some, like using leavened or unleavened bread for Consecration, are now considered "matters of custom," not requiring argument. Other matters are said to block reunification. One of these is Purgatory, for which EO does not even have a term, making a direct comparison difficult. We begin our analysis with the RC teachings on Purgatory, its locus, characteristics, and functions, and provide a simple relational network that shows Purgatory in relation to the afterlife, in particular to Heaven and Hell. With EO we begin with the teachings about life after death and provide a first approximation of Heaven and Hell and their relation to Paradise and Hades, both in characteristics and functions. Again, a simple relational network is enlightening. A surface comparison between the two networks distinguishes between those beliefs about the afterlife that are shared between RC and $\mathrm{EO}$ and those parts which house differences. It is these differences that must be subject to careful semiotic analysis to discover whether they are etic and possibly serious but not grounds for mutual excommunication or emic and a true barrier to reunification. We leave the possibly lengthy semiotic analysis for a subsequent study.
\end{abstract}

Keywords: Heaven, Hell, Purgatory, Paradise, Hades, emic/etic

The conference theme, "Controversy in Linguistics and Language Studies," demands a topic that is controversial and at least semi-linguistic. The conference venue at John Paul II Catholic University of Lublin brings to mind Pope John Paul's sincere desire for East-West reunification of the Church. But there is also a more personal reason that guided our direction. Our partnership has persisted over several years, many articles, 1.5 books and continues here, although our perspectives may differ: WJS is Roman Catholic (hereafter, RC) and ST is Eastern 
Orthodox (hereafter, EO). All these things distilled down to our title. In spite of its tooambitious scope, we were determined to make a start, at least to define a part of the problem.

As a Slavist, WJS has known many Orthodox Christians well: teachers and colleagues, Russians, Ukrainians, Bulgarians, and a Serb or two. When WJS discussed with them what was blocking reunification, every one of them mentioned the papacy and the more sophisticated mentioned filioque. But the web sites consulted on RC-EO differences (e.g., Azkoul, 1994; Gregory, n.d.) mentioned Purgatory as well, counting it one of the top three problems. Of the three points of contention, the papacy is heavily embroiled in historical and political questions and filioque in philosophical ones, making each of them too ambitious a topic for a condensed format. So we set them aside in favor of Purgatory. It seemed that Purgatory offered the most meat for pure linguistic or semiotic analysis.

Our original intent was to compare RC teachings on Purgatory with the way an EO theologian characterized the RC teachings and to compare EO teachings on Purgatory with the way an RC theologian characterized the EO teachings. Ideally, this would enable us to isolate linguistic and semiotic differences between the two and highlight possible sources of misunderstanding.

But when ST consulted her priest on an approach to her part of the analysis we were about to undertake, she discovered that WJS had made a fundamental mistake. WJS asked one of his teachers how to say Purgatory in Russian and got the answer Чистилище [čistilišče]. This 1participle of the verb čistit' 'clean' combined with the suffix išče 'a large place' made sense, hence 'a (major) site for cleansing'. The mistake was that the teacher was providing a linguistic or dictionary answer, not a theological one. Or, as ST's priest put it, in EO there is no Purgatory; that is, there is no place called Purgatory as such. But he had an alternative suggestion, that we take a step back and compare RC-EO teachings on life after death.

\section{Redefining the Topic}

A topic can be studied in two approaches: inductive and deductive. Since RC has doctrines on Purgatory, we can define a set of its features, a deductive approach. EO, though lacking a distinct doctrine on Purgatory, still has developed doctrines on life after death. By examining these doctrines we may be able to identify a subset that, taken together, inductively provide something like the same effect as RC Purgatory. In this case, RC and EO would potentially be compatible or at least comparable regarding this issue.

In order to provide a reasonable argument within a short presentation, we should examine an outline of the teachings in both traditions to define the similarities and differences. Then semiotic analysis can be applied to the differences to determine which teachings are emic, which are etic, and contrast the differences. The present study is limited to identifying the scenarios that underlie the RC and EO teachings. 


\section{The Emic-Etic Dichotomy}

The emic-etic dichotomy, once central to Neo-Bloomfieldian phonological analysis, is the idea that a phoneme, e.g., /p/, can have different phonetic manifestations: unreleased [p-] in final position, aspirated $\left[\mathrm{p}^{\mathrm{h}}\right]$ in syllable onset position, and unaspirated [p] after [s]. Pike (1967) applied the emic-etic distinction to culture as a whole, not just its linguistic part. ${ }^{1}$ In the present context, examples of the emic issues are found in the Creed recited at each Mass and Divine Liturgy. An example of an etic difference is making the Sign of the Cross: Roman Catholics sign up-down-left-right, imitating the priest's movements, and Eastern Orthodox sign up-downright-left, providing a mirror image of the priest's movements. At the same time, this act in either etic variant represents a number of emic beliefs: Trinity, Crucifixion, Resurrection.

The term Purgatory is not in the Creed, but the general understanding is that $\mathrm{RC}$ accepts it and $\mathrm{EO}$ rejects it. The question becomes, does the presence or absence of the term constitute an emic difference, where a fundamental belief is present in one and lacking in the other, or is it an etic difference, manifesting only-or mainly-in labels? As ST's priest suggested, our topic is broader, teachings on life after death. We begin with an outline of RC teachings and an analysis of the major points with a description of their structure presented in a relational network.

This is followed by the same steps applied to EO teachings. As mentioned above, we stop short of a full discussion of the differences. Our present purpose is not to reach a conclusion, only to provide a platform for discussion and dialogue.

\section{The Afterlife in Roman Catholicism}

There are two eternal abodes separated by an unbridgeable chasm: Heaven and Hell. These two abodes dominate the scene. Heaven is the abode of God, the angels, and the saints. Here saint should be understood to include not only declared saints like St. John Paul, but all the souls of the faithful departed who have made it to Heaven. Hell, on the other side of the unbridgeable chasm from Heaven, is the abode of Satan, the other fallen angels, demons, and damned souls. But what about human souls that merit neither Heaven nor Hell at death? That is, they are not given over to Evil but are not pure enough to see God. Logic suggests the possibility of an abode that is neither Heaven nor Hell and distinct from them both: Purgatory. This is the topography of the realm(s) where the soul abides after death.

After death a soul undergoes particular judgement to account for its life on Earth: sins, offenses, and negligences vs. acts of faith, hope, and charity. At the end of the particular judgement, the unrepentant and irredeemable souls are consigned to Hell. Those not damned may have pure souls and ascend straight to Heaven. Those lacking that degree of purity go to Purgatory, and here they are made ready for Heaven. The details of what happens in Purgatory

The idea was discarded by generative phonology from the beginning, when Halle (1959) abandoned the idea of phonemic contrast. His arguments have been rebutted by many writers, including WJS and even some generative phonologists, notably those of the Optimality Theory perspective. 
are not clear. It seems from some Biblical passages (II Machabees 12:32 et seq., 43-46; Rev. 21:27; I Cor 3:13-15) to have a purifying fire. But is the emphasis here on purification (a positive action of recovery and relief) or on fire (flames that painfully burn away impurities)? Long ago one RC priest, possibly paraphrasing St. John Chrysostom on I Cor 42, explained to WJS that the main punishment in Purgatory is separation from God.

It is also unclear how long a soul must remain in Purgatory. However, it may be understood that the soul remains there until purified, at which point it may ascend to Heaven. At the end of the universe, the Apocalypse, only four last things remain: Death, Judgement, Heaven, and Hell. Purgatory will cease to exist and all the souls remaining there will ascend to Heaven. In short, all those initially sent to Purgatory are saved and will eventually gain Heaven.

Our more conventional linguistic studies are informed by Relational Network Theory, a connectionist theory of language that defines and characterizes phenomena based on their relationships to each other. It should be no surprise that the above scenario strikes us as completely amenable to formalized description in the relational network diagram in Figure 1.

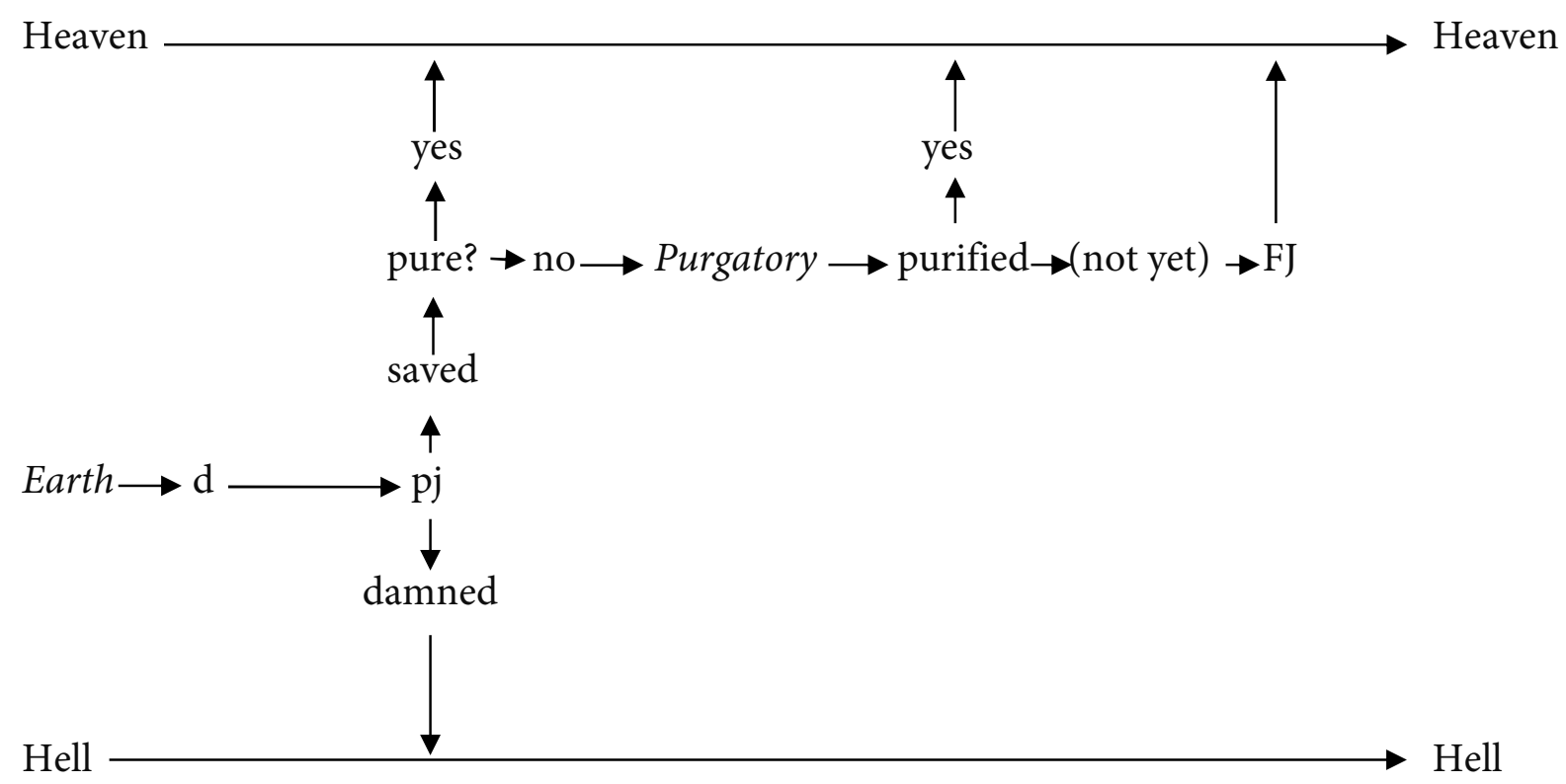

Figure 1: Life of the soul after death in Roman Catholicism

Heaven and Hell are well established at the point where the soul is infused in the newly formed and initially developing human person, no more than a few cells in size at most. The person lives out his or her earthly life, dying at (d). The soul undergoes particular judgement (pj) to determine whether it is saved or not. If not saved, it joins Satan and the other damned souls in Hell. If the soul is saved, it still must be examined for its purity. If pure, the soul ascends to Heaven. If not, it enters Purgatory for further purification. At any point the state of purity may be reached, especially if helped by the prayers, sacrifices, and Masses offered by the living, and the soul then ascends to Heaven. If not yet purified, the soul continues in Purgatory until the state of purity is reached. At the end of the universe and no later than the Final Judgement (FJ), Earth and Purgatory cease to exist. All the souls remaining in Purgatory have been purified and ascend to Heaven. Thus the RC teachings on Purgatory. 
We turn now to the EO teachings on the subject.

\section{The Afterlife in Eastern Orthodoxy}

The EO teachings on life after death are somewhat hard to pin down and in any event seem to be less formally defined than RC teachings, which are also sketchy. Still, an outline of sorts can be drawn up, though where it might lie on a scale from folk belief to formalized doctrine is impossible to say. In any case, our research has been performed in good faith and respectfully. The following synopsis draws largely from materials presented in Life after Death According to the Orthodox Tradition (2012), a comprehensive account of the topic by noted theologian JeanClaude Larchet that relies on both well established and lesser known sources. ${ }^{2}$

In general, the stages after death may proceed as follows. When a person dies, the soul remains on Earth for one to three days. The precise purpose of this is unclear, but in addition to other explanations, it may have its origins in the time Jesus's body remained in the tomb. The more secular-minded might cite a practical desire to make sure the deceased is not buried alive.

Between the third and ninth days, the soul is raised up past stations, according to numerous Patristic texts. Details about the stations along the way remain the subject of debate. Suffice it to say that the soul may be escorted through a series of stations representing the passions, perhaps twenty of them as described by Blessed Theodora, or seven corresponding to the Deadly Sins, where they must give an account of their actions relevant to that sin. During this time one or more angels are trying to lead the soul upward toward Heaven, while demons are trying to drag them down, toward Hell. This may parallel "particular judgment" from RC theology via theologians of Kiev in the 16th century (see further in Larchet, 2012, pp. 129 ff.).

From the ninth to fortieth days the soul may be introduced to the other world, the different parts of Heaven and the different parts of Hell. On the fortieth day, this process results in a decision, whether the soul is mostly good (or mostly evil), and consequently, whether it is housed in Paradise or Hades, there to remain until the Apocalypse. Note that a soul initially assigned to Hades may, through the intercession of saints or the prayers of the faithful, gain Paradise (not shown in Figure 2).

At the Apocalypse and the Final Judgement, Paradise and Hades cease to exist. The souls in Paradise ascend to Heaven and the souls in Hades descend to Hell. The effect would be the same if Paradise and Hades with their resident souls simply merge with Heaven and Hell.

These teachings are summarized in relational network form in Figure 2.

Figure 2 should be read as follows. The soul's abode is in the body on Earth until death at (d). Between (d) and its afterlife journey, possibly through stations (s), the soul remains on Earth. At (s) the soul enters the judgement stations, for example seven of them, and is either on the path upward toward Paradise, or the path downward, toward Hades, with the help of angels or because of the impeding efforts of demons. Again, this perhaps approximates the particular judgement (pj) in RC. The time spent in traversing is not represented. At the Last Judgement, that is, a final judgement (FJ), Paradise disappears or merges with Heaven and all the souls that

2 This book was brought to our attention by Fr. Cosmin Sicoe of Lexington, KY, who also shared insights on EO teachings on life after death and their doctrinal status. Any errors in interpretation are our responsibility. 
had been in it would expect to ascend to Heaven. At the same time, Hades disappears or merges with Hell, and the souls resident therein would expect to descend to Hell.

Figures 1 and 2 represent mere outlines of two belief systems. As such, they may simplify or gloss over unfairly many subtle factors in one or the other of the systems. Oversimplification is not our intent; rather, we wish to establish the boundaries around our topic. Our outline is focused on a single soul, because it is the individual who finds salvation or damnation.

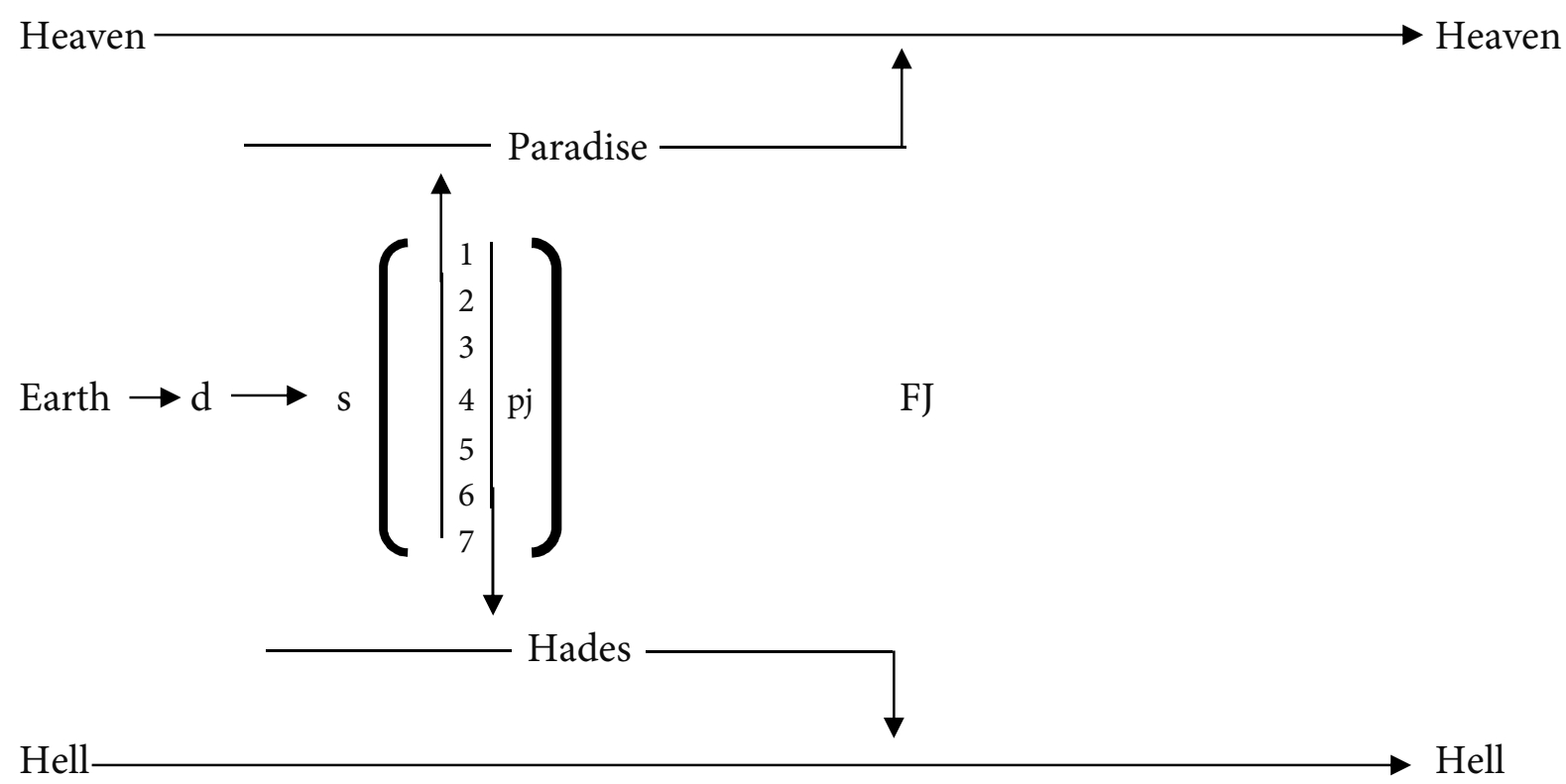

Figure 2: Life of the soul after death in Eastern Orthodoxy

\section{A Direct Comparison}

The parallels and differences between the EO and RC beliefs about the afterlife are easily discerned by a juxtaposition of Figures 2 and 1 .

Note that the same things are eternal in both RC and EO networks: Heaven, Hell, and the individual soul. Earth and any other abodes are temporal. Ultimately the pure souls ascend to Heaven, the evil and damned descend to Hell. At the last or final judgement, only Heaven and Hell are left. Not everything between the Heaven and Hell axes is different, but all the differences are between them. Is there Paradise and Hades or singular Purgatory? Can at least some souls reach Heaven (or Hell) before the Final Judgement in Eastern Orthodoxy?

Not everything there is contrastive, however. The EO stations at (s) in Figure 2 may as well correspond to the particular judgement (pj) in Figure 1. They are in roughly the same position in both networks and they are certainly very similar functionally. Other differences glossed over or ignored in this broad contrast may be similarly equivalent.

Still, there are differences. The real discussion must begin when we try to determine whether these differences are emic, i.e., defining and crucial to the Faith, or whether they are etic, i.e., however important culturally and in practice, not crucial to the Faith. We do not dismiss such etic differences: Lex orandi, lex credendi 'the law of praying is the law of believing' 
or, more informally, as we pray, so we believe. A saint recognized in EO and not in RC (or the reverse) is important, but not cause for a schism.

In sum, there is material for discussion that could put us one very small step closer to a reunification of RC and EO.

\section{Afterword}

During the discussion period following this paper at LingBaW2016, Razvan Saftoiu of the Transilvania University of Brasov, Romania, identified himself as a member of the Romanian Orthodox Church and pointed out the existence of many cultural differences in worship between EO and RC. We acknowledge these and agree to their importance. We would never suggest that they be either discarded, downgraded, or glossed over in a misguided attempt at ecumenism. In fact, this is an important part of the complaints of more traditional RCs against the "major, if not tragic attempt, to 'update' Roman Catholicism" in the spirit of Vatican II (Azkoul, 1994). We would maintain that such badly thought out changes violate the old maxim, Lex orandi, lex credendi. EO has nothing to fear from our work on that score.

Is there any hope for a project like this? A historic treaty that formalized the admission of the Ukrainian Greek Catholic Church into full communion with the Roman Catholic Church admitted to differences in the teachings on Purgatory but agreed to disagree on the details (Halsall, 1999). If such an accommodation is acceptable more generally, there is.

\section{References}

Azkoul, Fr. Michael. What are the differences between Orthodoxy and Roman Catholicism? Reproduced with permission from The Orthodox Christian Witness, Vol. XXVII (48), Vol. XXVIII (6) and (8). 1994. Retrieved from http://www.ocf.org/OrthodoxPage/reading/ortho_cath.html, 1 Feb 2017.

Catechism of the Catholic Church, 2nd Edition. 2000. Retrieved from http://www.vatican.va/archive/ENG0015/_ P2N.HTM, 1 Feb 2017.

Connell, Fr. Francis J. 1949. The Revised Baltimore Catechism. Colorado Springs: ATI.

Davies, Maximos. 2007. What Divides Orthodox and Catholics? Dec 3, 2007. Retrieved from http://www.america magazine.org/faith/2007/12/03/, 1 Feb 2017.

The Differences between the Catholic and Orthodox Churches. Feb 12, 2016. Retrieved from http://www.econom ist.com/blogs/economist-explains/2016/02/, 1 Feb 2017.

Gregory, Fr. (n.d.) Orthodox Christianity for Absolute Beginners: Roman Catholicism and Orthodoxy Compared. Retrieved from www.orthodoxresource.co.uk, 1 Feb 2017.

Halle, Morris. 1959. The Sound Pattern of Russian. The Hague: Mouton.

Halsall, Paul. 1999. Modern History Sourcebook: The Treaty of Brest, 1595. Retrieved from http://sourcebooks.fo rdham.edu/halsall/mod/1595brest.asp, 1 Feb 2017.

Hierotheos, Metropolitan of Nafpaktos. (n.d.) Life after Death Ch. 5, The purifying fire. Trans. Esther Williams. Moni Pelagias, Greece: Birth of the Theotokos Monastery. Retrieved from http//www.orthodoxservices.org/ purifying_fire.htm, 1 Feb 2017.

Larchet, Jean-Claude. 2012. Life after Death According to the Orthodox Tradition. Trans. G. John Champoux. Rollinsford, New Hampshire: Orthodox Research Institute.

Pike, K.L. 1967. Language in Relation to a Unified Theory of the Structure of Human Behavior. 2nd ed. The Hague: Mouton. 
Roman Catholicism and Orthodoxy Compared. Retrieved from http://www.orthodoxresource.co.uk/comparativ e/roman-catholic.htm, 1 Feb 2017. 